\title{
Mixed-use development in a high-rise context
}

\author{
Elena M. Generalova ${ }^{1, *}$, Viktor P. Generalov ${ }^{1}$, Anna A. Kuznetsova ${ }^{1}$, and Oksana N. \\ Bobkova $^{1}$
}

${ }^{1}$ Samara State Technical University, Institute of Architecture and Civil Engineering, 443001, Samara, Molodogvardeyskaya St, 194, Russia

\begin{abstract}
The article deals with an actual problem of finding techniques and methods to create a comfortable urban environment. The authors emphasize that in the existing conditions of intensive urban development greater attention should be given to spatial concentration based on and more compact distribution of population in urban space. It is stressed that including mixed-use facilities into urban realm results in a significant improvement of living environment qualitative characteristics. The paper also examines modern approaches to constructing a «compact city» for comfortable and convenient living with a mixed-use tall building development. The authors explore the world's experience of designing tall mixed-use buildings and reveal modern trends in their construction. The statistics given is based on the data analysis of a group of tall mixed-use buildings consisting of more than 400 objects, constructed in 2007-2016. The research shows functional and architectural peculiarities of this typology of tall buildings and investigates a mechanism of creating zones of mixed-use tall building development in the urban structure. In conclusion, the authors consider prospects of development and major directions of improvement of mixed-use tall building parameters for a reasonable territorial urban growth and creation of high-density and comfortable building development.
\end{abstract}

\section{Introduction}

Massive world urbanization is accompanied by an alarming tendency for urban sprawl of city areas. Leading specialists in architecture, urban planning, economics, sociology, ecology, etc. are worried about it and try to find new, more rational urban planning and space-planning solutions to meet the challenges of modern society. In these circumstances, the concept of «sustainable vertical urbanism» based on finding a totally new typology of tall buildings seems appropriate and develops rapidly. This typology is based on the principle of multi-functionality. The term «multifunctionality» denotes the ability of a large system to perform many functions. In this paper, «functions» are urban services which are different types of activities in urban area (housing, industry, health care, trade, education, etc.). «Multifunctionality» as a phenomenon of urban environment has been studied by many researchers [1-13].

\footnotetext{
* Corresponding author: generalova-a@yandex.ru
} 
In the 80-ies of XX century, A.E. Gutnov (a Soviet architect and a theoretician of architecture and urbanism) created a term «urban layout», saying that it was «a relatively separate, functionally connected area of spatial environment, within which a set of basic types of social activity, resulting from the present level of society development, is performed». He stressed that the basis of an urban layout was a «framework», which defined the spatial form of the modern city and had an ability for growth and transformation. Such a framework included «highways and transport nodes, multilevel spatial structures with an extensive network of internal communications» [13]. A.E. Gutnov also emphasized the degree of a city's «communication characteristics» meaning the intensity of its territory development and its connection with the efficiency of location and spacing as a value measured by time spent on traveling around the city because of basic social necessities.

Some earlier statements about the necessity of an urban environment multi-functional development sounded mostly as criticism of cities territorial zoning (based on functional processes typical for a city). Recent studies, however, see the «framework» of the city in a new light as there is an urgent need for spatial concentration of urban realm in vertical direction. There is an active search for a modern innovative concept of a «compact city» with new types of tall buildings, which are developed as integrated mini-cities providing high density residential development. Here, we find it important to emphasize that high density residential development will be able to satisfy requirements for high quality of life only through the integration of various urban services that contribute to the formation and full development of the personality.

\section{Methods}

In view of the above, this study aims to analyze the multi-functional typology of mixed-use tall buildings and its current state of development as well as to estimate its prospects. The analysis was made on the interactive database «CTBUH Skyscraper Center» containing information about more than 10000 tall buildings. Therefore, it is appropriate to accept a definition of tall mixed-use buildings given by CTBUH (The Council on Tall Buildings and Urban Habitat): «A mixed-use tall building contains two or more functions (or uses), where each of the functions occupies a significant proportion (15 percent or greater of either) of the tower's total space. Support areas, such as car parks and mechanical plant space, do not constitute mixed-use functions. Functions are denoted on CTBUH «Tallest» lists in descending order (e.g., «hotel/office» indicates hotel function above office function)» [14].

The first building, which satisfies to CTBUH criteria for mixed-use tall buildings, was built in Chicago in 1924. It was «Chicago Temple Building» (office/religious) $173.1 \mathrm{~m}$ high. Apart from offices, it fulfills another independent function - a religious one. On the first floor of this building there is the First United Methodist Church of Chicago that can accommodate nearly 1000 people. On the second floor, there is Dixon Chapel and the church administration. There are rooms for a Sunday school, a Conference Hall and a room for the church choir on the third and fourth floors. Subsequent levels (Floors 5 to 23) hold offices which are rented to various commercial organizations. There is also the so-called "Sky chapel" at a height of 120 meters at the base of the Spire. It has room for 30 people.

In the XX century, within the period of 1924-2000 (76 years), 96 mixed-use tall buildings above $150 \mathrm{~m}$ high were constructed all over the world. In the XXI century, within the period of 2000-2016 (16 years), 499 mixed-use tall buildings above $150 \mathrm{~m}$ high were built. These figures prove that there is definitely a growing interest in mixed-use tall buildings). However, if we relate mixed-use tall buildings with the total number of skyscrapers built during this period, we can conclude that single-function tall buildings prevail. Thus, over the past 10 years (2007-2016) 2071 tall buildings above $150 \mathrm{~m}$ high 
were built in the world. From that number, only 410 objects can be described as mixed-used buildings. That is only $20 \%$ of the total number. The study focuses further on these 410 skyscrapers, which we refer to as called «the analyzed group» (see Fig. 1).

The research identifies a current trend of the intensity of construction of mixed-use tall buildings during this ten-year period in the following years:

- 2007 - 43 buildings, 22 being of mixed-use (15.4\%);

- 2008 - 218 buildings, 38 being of mixed-use (17.5\%);

- 2009 - 203 buildings, 37 being of mixed-use (18.3\%);

- 2010 - 195 buildings, 36 being of mixed-use (18.5\%);

- 2011 - 200 buildings, 32 being of mixed-use (16.0\%);

- 2012 - 170 buildings, 33 being of mixed-use (19.5\%);

- 2013 - 178 buildings, 35 being of mixed-use (19.7\%);

- 2014 - 261 buildings, 50 being of mixed-use (19.2\%);

- 2015 - 253 buildings, 61 being of mixed-use (24.2\%);

- 2016 - 250 buildings, 668 being of mixed-use (26.4\%).

It can be seen there is a definite increase both in the intensity of high-rise construction and in the percentage of mixed-use tall buildings. Functions, mixed-use tall buildings can perform, include: office, residential, serviced apartments, hotel, retail, exhibition, casino, etc. According to the degree of their development, these functions can be divided into 3 main types: «dominating», «additional» and «accompanying». According to their «dominating» function, 410 mixed-use tall buildings in the analyzed group are of the following types: the «residential» function (including serviced apartments) prevails in 50\% of buildings (202 buildings); «hotel» function goes second with 34\% (138 buildings); the «office» function with $17 \%$ (70 buildings) is the third.

Buildings combining only two main functions are most common, their proportion is about $85 \%$. Only 60 objects from «the analyzed group» combine 3 or more functions. «three-dimensional» multi-layer urban environment development and serve as basis for creating a new typology of tall buildings.

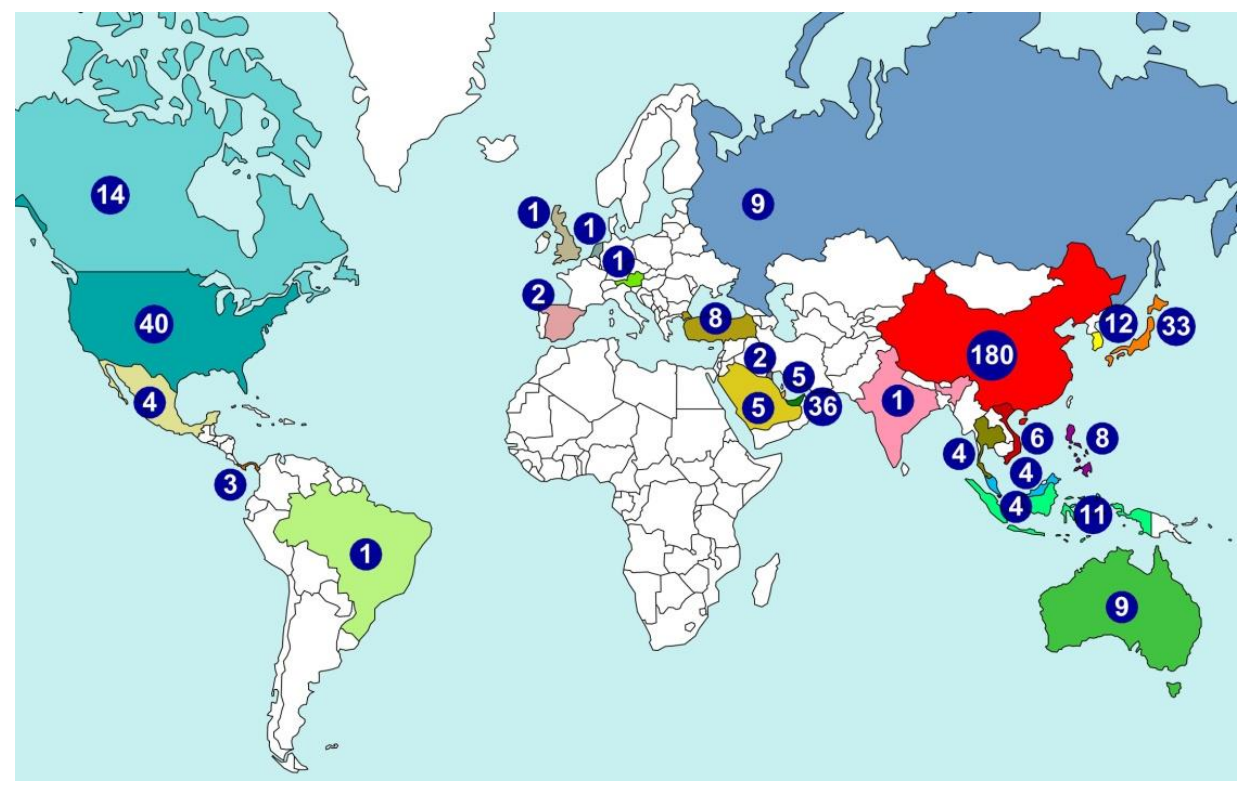

Fig. 1. Mixed-use tall buildings above $150 \mathrm{~m}$ high, built in 2007-2016 on the world map. 


\section{Results}

From a bird's perspective or on a cityscape many mixed-use tall building look like conventional high-rise towers, often significantly dominating above the surrounding buildings. Their true environment-forming role can be seen only when you thoroughly analyses how these large-scale objects have been integrated into the urban environment, especially at the level of its connection to pedestrian and traffic flows. Talking about the effective integration of mixed-use tall buildings in the current building development, one of the most important criterion - the degree of «openness» of a building into the urban space should be mentioned. It is very important that the building, which includes many functions and services, does not become an unassailable fortress where housing is available only for the tenants, offices - for the employees and a hotel - for its guests. Thus, a reasonable balance between the «isolation» and «openness» is required. «Isolation» is necessary for a few processes, ensuring their safety and optimum performance. "Openness», which means availability in general, availability for transit, etc., is important both for the dissolution of the object in the urban space, and for the improvement of urban infrastructure efficiency.
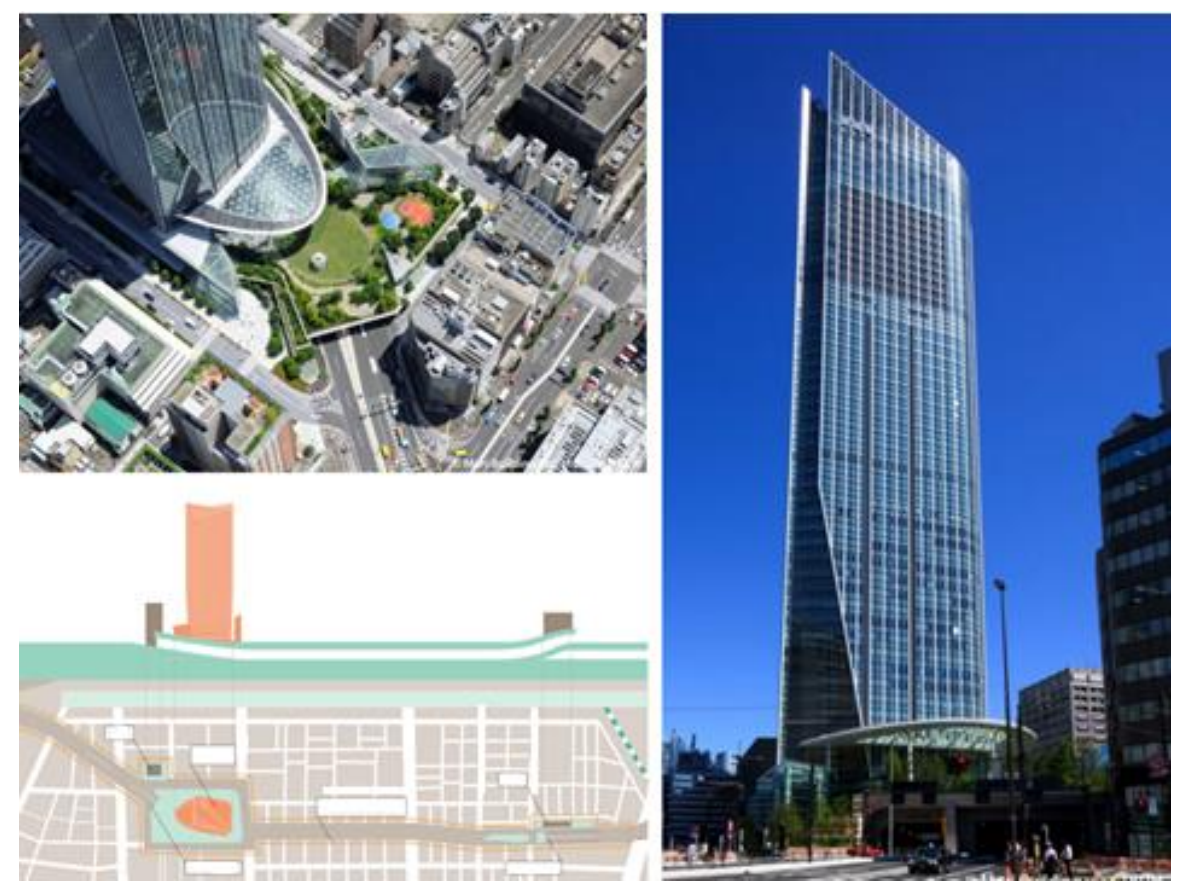

Fig. 2. «Toranomon Hills», Japan, Tokyo, 2014, 258 m, 52 floors, designed by Nihon Sekkei [12].

«Toranomon Hills» (office/residential/hotel, $258 \mathrm{~m}, 52$ floors), a complex built in Tokyo in the 2014 upon the project of Nihon Sekkei, is a remarkable example of quality architecture. A notable feature of this project is the active use of its underground space for additional compactness of planning solutions and the integration of all functions with the transport system of the city. An underground tunnel, buried under the building, with a highway in it (see fig. 2) is an important part of this design concept. The space above the underground track is released for pedestrians at ground level; a 40-meter wide avenue with wide sidewalks about 13 meters wide is constructed there. To avoid any vibration from traffic on this tall building, the tunnel is designed independent of the building structure and 
is further isolated by using a special vibration-damping material. There 52 floors above ground and 5 underground levels, serving as a parking lot, in this building. Floors 1-5 hold shops, conference halls, cafes and restaurants. Offices, located on Floors 6-35, are of the «dominant» function. Floor 36 is a technical floor which in itself is a unique structural frame serving to change column spacing from Floor 37 and above. Floors 37-46 serve as housing accommodations, and Floors 47 and above are given to a hotel. «Toranomon Hills» is integrated into the urban environment through a massive green public space used as the center of social activity area. The park is located at the bottom of the tower on the basement roof. There is a rooftop bar, available to everyone, on top of the tower [15].

This is not the only example, where tall mixed-use buildings designs are actively linked with the transport system of the city. "Abeno Harukas», a complex built in Osaka in 2014, is considered to be the world's only building of this scale (300 m high), located directly above a train station (the Abenobashi Station). This train station, «Kintetsu», is located on the second floor, its capacity exceeding 70000 passengers per day. The complex is a real high-rise vertical city with a maximum capacity of 110000 people. It has 60 floors and 5 underground levels with various functions: a terminal station, a department store, an art museum, offices, a hotel, an observatory, a clinic, a school, parking spaces, etc. The department store occupies sixteen floors - two underground levels and 14 floors above ground. The art museum is located on the sixteenth floor. There is a wide variety of works, including the Western and modern art, in it. The observation deck «Harukas 300» (Observatory) is one of the main attractions of this skyscraper, it is located on the 58-60 floors and holds a garden and an open-air café. The internal volume of the building is filled with free public spaces that are also involved in the ventilation system and heat transfer of the whole construction. A stepped shape of the building allowed to create additional public green areas at different levels (see Fig. 3). The building construction is integrated with several technologies aimed at reducing emissions of carbon dioxide into the atmosphere, an innovative technology of urban biogas system for the building being among them. The tower is connected with the existing urban realm through public pedestrian bridges, built on different floors $[16,17]$.
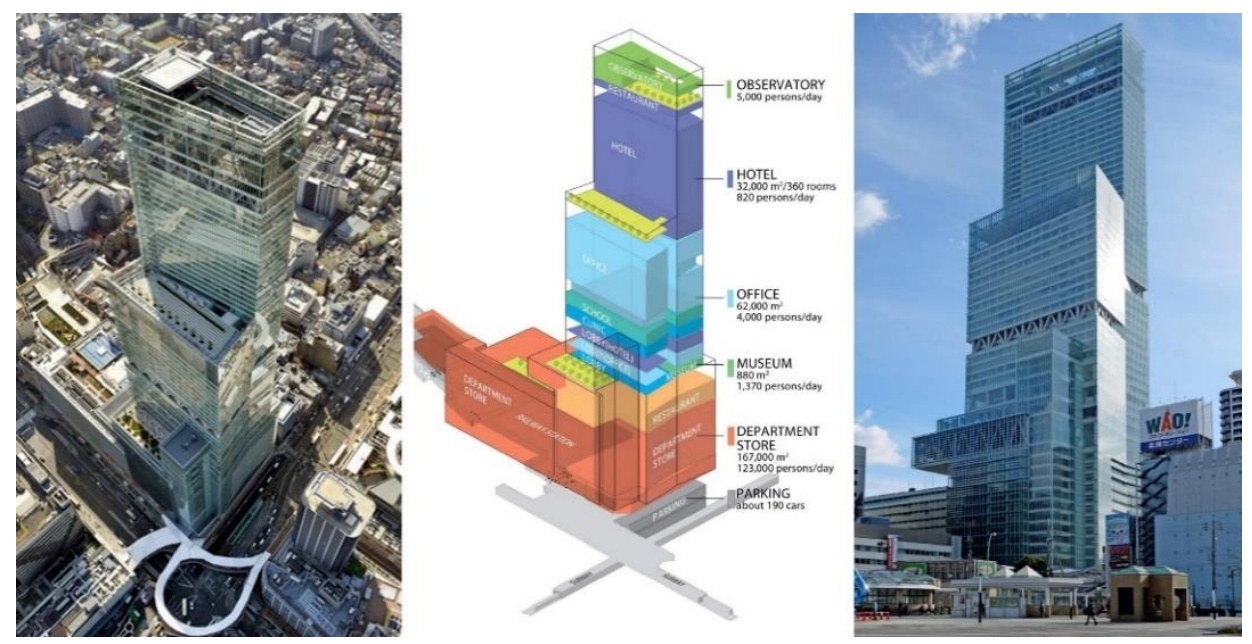

Fig. 3. «Abeno Harukas» (Osaka, Japan, 300 m, 60 floors, 2014, hotel/office/retail. Takenaka Corporation [http://skyscrapercenter.com/building/abeno-harukas/533].

Talking about the methods of tall buildings integration into the urban environment from the point of view of their connection to the transport system of the city, one should mention «The Shard» (306 m, 73 floors, residential/hotel/office), a skyscraper in London. It was 
built in 2013, on the former territory of Southwark Towers office complex, and is located next to a train station. In this tall building, Floors 3-28 hold offices, Floors 31-33 house restaurants, the 200-room Shangri-La Hotel is situated on Floors 34-52, and the next block is for housing accommodations (Floors 53-65). A public observation deck (Floors 68-72) crowns the building. The construction of this super tall building next to a major transportation hub, in a city that has a rich historical heritage, introduced several innovations. The construction team had to reconsider basic principles of construction and make use of entirely new methods. Thus, while constructing the concrete core, a top-down construction technology was used for the first time. Because of this technology the first 23 floors of the concrete core and much of the surrounding tower had been built before the basement was fully excavated. Besides, a special drilling rig, which allowed to place piles in underground communications of the Victorian era with an extremely high precision, was specially design for the construction. Today, «the Shard" is a new symbol of London, a key link in the newest commercial quarter giving powerful energy to revive the entire southern shore of London [18].

\section{Discussion}

The result of the work on the analysis of the structure of mixed-use tall buildings and methods of their integration into the urban environment would be incomplete, if we do not consider the future to consider development prospects of this typology of buildings. It is planned that in 2017 new 108 mixed-use tall buildings will be erected. Among these buildings, 13 have already been built. Three buildings here can be referred to the category of super tall buildings:

1 - «Lotte World Tower» (Seoul, 554,5 m, 123 fl., hotel/office/retail);

2 - «Address Boulevard Dubai» (Dubai, 368 m, 72 fl., serviced apartments/hotel);

3 - «Zhuhai IFC», (Zhuhai, China, $330 \mathrm{~m}, 67 \mathrm{fl}$. hotel/office).
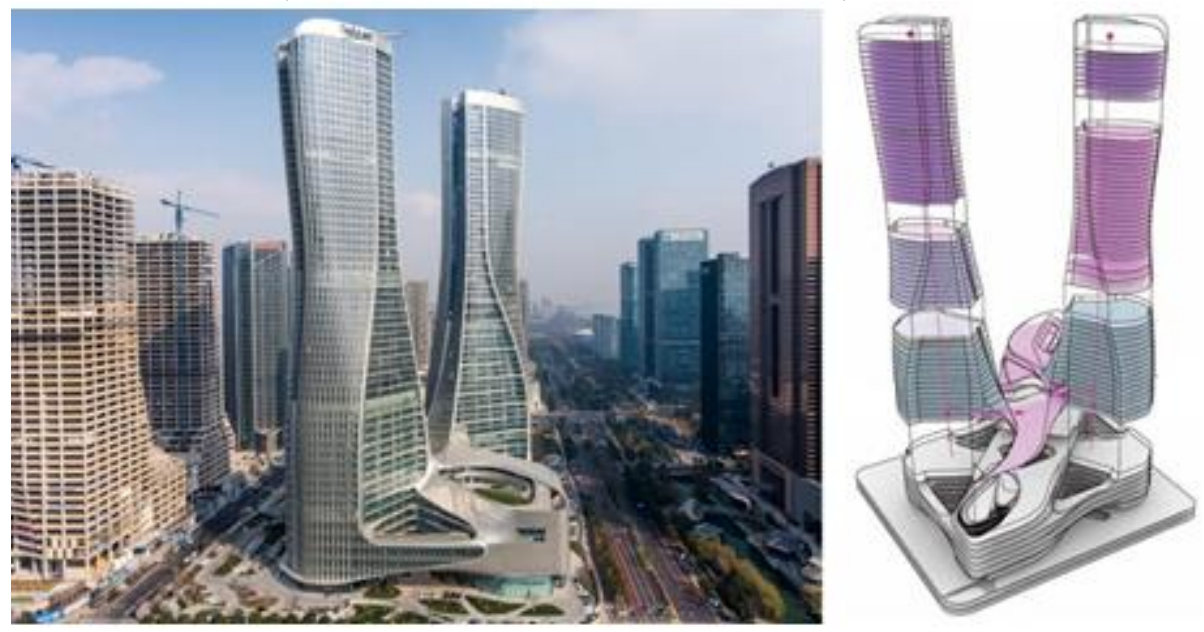

Fig. 4. «Raffles City Hangzhou Tower» (250,0 m, 60 floors, China, City Hangzhou (residential / hotel / office), UN Studio [http://www.unstudio.com/projects/raffles-city-hangzhou].

However, we would like to describe a few sites which are not that tall. The first here is a complex named «Raffles City Tower Hotel Hangzhou» (China, City Hangzhou, 250.0 m, $60 \mathrm{fl}$.) with its unique space-planning decision. The building is in its final stages of construction and incorporates retail, offices, housing and hotel facilities. This project 
consists of two tall intertwining twin towers at the podium and a three-storey underground parking. According to the designers, its characteristic feature is a close interconnection of the landscape aspect with the urban context (see Fig. 4). The project involves a huge amount of technical and engineering features that are implemented while using digital engineering through building information modelling, virtual construction planning and simulation [19].

Singapore complex «Marina One» (see fig. 5) will also make a significant contribution to the formation of a new typology of tall buildings after its completion. It is a high-density, mixed-use building complex in the heart of a new financial district. The basis of its concept is turning Singapore into a "Garden City». This concept is implemented through the creation of internal public space fringed by office buildings and housing accommodations, as well as a podium with shopping and entertainment function. It is the largest public Plaza in the Central Business District) which is supplemented by green areas at different levels of the complex. The perimeter formed by the buildings is not completely closed. The towers have a porous structure, which provides good air circulation, ensures natural ventilation and sustains a comfortable internal climate. Environmental sustainability and energy efficiency are achieved though introducing a variety of technologies: external sun-protection devices and high performance glazing, centrally provided recycled water for toilet flushing, rainwater harvesting system, photovoltaic cells, and more. The complex is connected to the four lines of the Metro (MRT) and bus terminals [20].
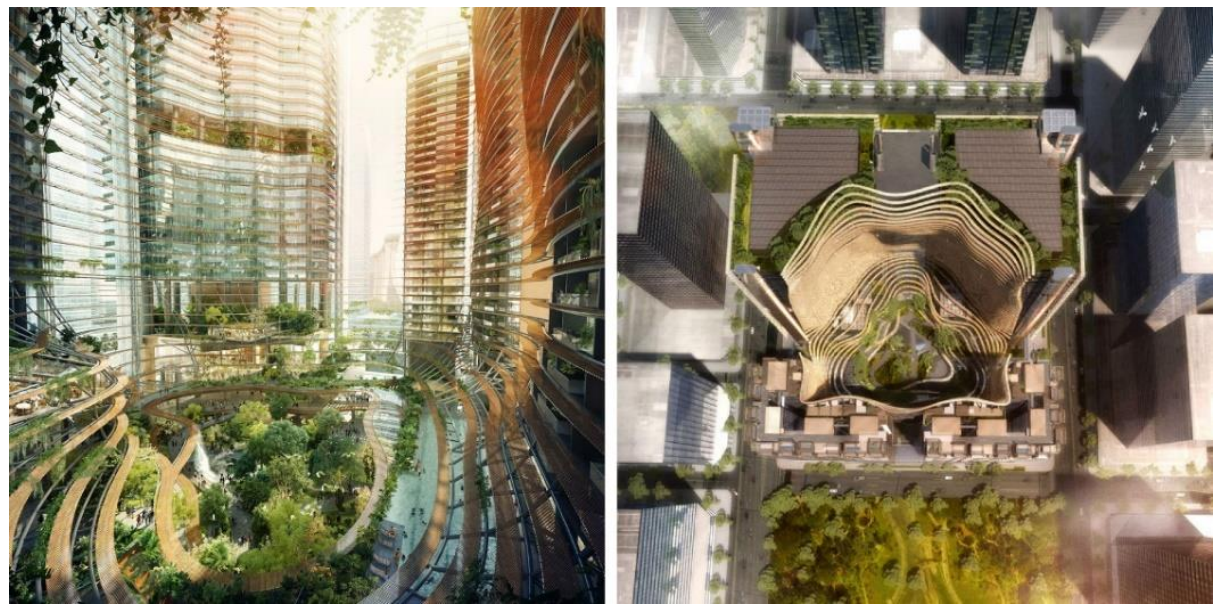

Fig. 2. «Marina One» (Singapore, 225,4 m, 30 floors, residential/office/retail). Ingenhoven Architects \& A61. [http://www.ingenhovenarchitects.com/projects/more-projects/marina-one-singapore/]

\section{Conclusions}

Summarizing the results of the analysis, it should be noted that the typology of mixed-use tall buildings is being actively developing. This development is aimed at searching a modern interpretation of the concept of the vertical city, where people can live, work and relax. Even though today among mixed-use tall buildings three buildings have surpass the mark of $600 \mathrm{~m}$ and there are 47 buildings above $300 \mathrm{~m}$ high, we can confidently say that «a race in the vertical direction» is not a philosophical basis of design concepts discussed above and implemented in the unique complexes under analysis. The most important criteria for the quality of these buildings architecture are the following approaches, techniques and methods of their integration into the urban environment: town planning; space-planning; engineering; technological; integration through transport infrastructure; 
integration through the creation of public spaces and pedestrian links with surrounding buildings; because of a reasonable balance between the «isolation» and «openness» of different functional areas within buildings, etc. In conclusion, we would like to stress that a proper integration of mixed-use tall buildings will allow to create a convenient and comfortable living environment and to improve environmental and economic status of existing cities.

\section{References}

1. V. P. Generalov, E. M. Generalova, Sustainable architecture, Energy Efficiency and Sustainability of Affordable Housing on the Example of Hong Kong, Vestnik of SGUACE. Town Planning and Architecture, 4(21), 23-29 (2015) DOI 10.17673/Vestnik.2015.04.3.

2. E. M. Generalova, V. P. Generalov, A. A. Kuznetsova, Modular Buildings in Modern Construction, Procedia Engineering, 153, 167-172 (2016)

3. T. Y. Vavilova, N. D. Potienko, I. V. Zhdanova, On Modernization of Capital Construction Projects in the Context of Sustainable Development of Social Sphere, Procedia Engineering, 153, 938-943 (2016)

4. V. P. Generalov, E. M. Generalova, Revealing the Special Features of the Concepts "Comfortable living" and "Comfortable living environment", Vestnik of SSUACE, Town Planning and Architecture, 2(23), 85-90 (2016) DOI 10.17673/Vestnik.2016.02.16.

5. E. M. Generalova, V. P. Generalov, Specific Features of Modern Architectural and Spatial Environment of Cities and Its Formation (with South Korea as an Example), Scientific Survey, 11, 46-51 (2015)

6. E. M. Generalova, V. P. Generalov, Super Thin Residential Skyscrapers in New York as a New Trend in the Typology of Tall Buildings, Town Planning and Architecture, 4 (25), 85-91 (2016) DOI: 10.17673/Vestnik.2016.04.16.

7. A. Y. Zhigulina, N. G. Chumachenko, Choosing Building Materials to Improve Comfort and Ecological Safety of Residential Buildings, Vestnik of SGUACE. Town Planning and Architecture, 4(21), 94-99 (2015) DOI 10.17673/Vestnik.2015.04.12.

8. A. A. Kolosovskaya, N. D. Potienko, Evolution of the Typological Structure of Rental Accommodation Abroad, Town Planning and Architecture, 3(24), 109-115 (2016) DOI: 10.17673/Vestnik.2016.03.12.

9. M. Balzannikov, V. Alpatov, I. Kholopov, A. Saharov, A. Lukin, Usage of Spatial Lattice Metal Structures as Roofing for Mechanical Equipment Rooms of Hydroelectric Power Stations, MATEC Web of Conferences, 73, 01012 (2016)

10. A. O. Mateyko, Development History and Current Trends in High-rise Construction, Town Planning and Architecture, 3(24), 74-78 (2016) DOI: 10.17673/Vestnik.2016.03.12.

11. S. A. Kolesnikov, Town-Planning Principles of High-Urbanized Multi-Functional Units Formation of the largest city urban structure, Vestnik MGSU, 3, 25-29 (2009)

12. T. Ya. Vavilova, International Experience in Rehabilitation of Depressed Residential Areas for Sustainable Development, Architeckton: News of Higher Educational Institutions, 49, 4 (2015)

13. A. E. Gutnov, Evolution of Urban Planning, 256 (Moscow, Stroiizdat, 1984) 
14. http://www.ctbuh.org/TallBuildings/HeightStatistics/Criteria/tabid/446/language/enUS/Default.aspx (last accessed Apr. 3, 2017)

15. Y. Hitomi, H. Takahashi, H. Karasaki, Toranomon Hills - Super High-Rise Building on Urban Highway, International Journal of High-Rise Buildings, 3(3), 167-171 (2014)

16. K. Hirakawa, K. Saburi, S. Kushima, K. Kojima, Performance-Based Design of $300 \mathrm{~m}$ Vertical City «Abeno Harukas», International Journal of High-Rise Buildings, 3(1), 35-48 (2014)

17. T. Harada, M. Yonezu, Forging a Supertall Compact City, CTBUH Journal, II, 12-20 (2015)

18. I. Sellar, Developing an Icon - The Story of the Shard. Proceedings of the CTBUH 2015 International Conference "Global Interchanges: Resurgence of the Skyscraper City» 26th-30th October, 138-145 (New York, USA, 2015)

19. A. Wang, Raffles City in Hangzhou China - The Engineering of a 'Vertical City' of Vibrant Waves, International Journal of High-Rise Buildings, 6(1), 33-47 (2017)

20. http://skyscrapercenter.com/building/marina-one/16878 (last accessed Apr. 3, 2017) 